\title{
УДК 32
}

\section{РОССИЙСКИЙ БИЗНЕС В ЭПОХУ САНКЦИОННЫХ ПЕРЕВОРОТОВ: ПРОБЛЕМЫ И ПЕРСПЕКТИВЫ}

\section{Подобаев Владислав Юрьевич}

ФГБОУ ВО Северо-Западный Институт управления РАНХиГС

Аннотация: Изменение международной структуры провоцирует появление новых проблемных зон, сопровождая это кризисом в политическом, экономическом секторах. Решение проблемы должно быть обоюдным желанием. Статья ярко продемонстрирует то, как в кризисных ситуациях Россия справляется с тяжелой международной повесткой дня в условиях санкций.

Ключевые слова: санкции, международное сотрудничество, международно-правовые нормы, потенциал, динамика развития.

\section{RUSSIAN BUSINESS IN THE ERA OF SANCTIONS COUPS: PROBLEMS AND PROSPECTS}

\section{Podobaev Vladislav Yurievich}

\begin{abstract}
The change in the international structure provokes the emergence of new problem areas, accompanied by a crisis in the political and economic sectors. The solution to the problem should be a mutual desire. The article will vividly demonstrate how in crisis situations Russia copes with a difficult international agenda in the face of sanctions.
\end{abstract}

Key words: sanctions, international cooperation, international legal norms, potential, development dynamics.

Динамичное развитие природы международных отношений зависит от его основополагающих факторов: взаимодействия участников межгосударственных отношений в политической, экономической, культурной и социальных средах. Неизбежно сменяемая конъюнктурность международных систем дала в совокупности новый виток в истории, заложила 
основы международно-правовых норм, создала механизмы регулирования отношений между государствами, её экономический обмен. Иными словами, можно полагать, что опыт прошлого помогает заранее предотвращать проблемы нынешнего времени и разрешать конфликтные ситуации путём мирного урегулирования.

Однако не всегда такие способы могут применяться в международной практике. С течением времени, изменением геополитической ситуации, можно проследить, что конструкция мирового порядка сдвигается в сторону подрыва основополагающих принципов международного сотрудничества. Нарушение международного права, совместных соглашений вплоть до действий в одностороннем порядке, направленных на эскалацию конфликта, демонстрируют государства, чьи интересы тесно сталкиваются с Российской Федерацией.

За многие годы, Россия придерживалась и придерживается классической дипломатии и внешней политики, которая была заложена титанами русской дипломатической школы. Выполняя обязательства перед международным сообществом, Российская Федерация сталкивается с рядом трудностей в международной среде: во внешней политике, бизнесе, культурном обмене и многих других.

В 2020 году углубились старые разломы и появились новые. Внутриполитические изменения, плавно переходящие от одного государства к другому, нерешенные территориальные споры, а также вирус, отправивший на тотальную изоляцию весь мир и перестроивший формат очного сотрудничества- COVID-19. Вирус поразил мировое сообщество не только своими болезненными симптомами, но и ударами по экономическим и бизнес структурам. Какие именно проблемы сейчас стоят перед российскими компаниями на международном уровне и какие перспективы возможны для дальнейшего развития?

Опыт показал, что российские компании на международном уровне показывают достойную работу, несмотря на ряд возникающих трудностей в процессе постоянно меняющейся политико-экономической ситуации. И, разумеется, основная трудность для компаний - санкции, постепенно увеличивающиеся по своему масштабу и количеству. Тем не менее, российские бизнес структуры и крупнейшие компании находят выход из сложившегося положения, основанного на предвзятости и необоснованности убеждений многих иностранных партнеров. 
После референдума в Крыму и его присоединения в состав Российской Федерации в 2014 году, мировое сообщество, основываясь на личных убеждениях, продемонстрировало свое отношение, которое пагубно повлияло на отношения с Россией, в первую очередь, в политическом, экономическом плане. Эти события повлекли за собой многочисленные санкции в адрес Российской Федерации, затормозив международное сотрудничество.

Одним из решений со стороны России в обход действующих санкций прозвучала инициатива со стороны Минэкомразвития РФ. Предлагается на территории Крыма и Севастополя создать особые административные районы с особым правовым режимом, в которых инвесторы могут работать, не опасаясь санкций, анонимно. Предшествуя этой инициативе, Правительством было разрешено зарегистрированным юридическим лицам скрывать данные о своей деятельности для обхода санкций.

Помимо стабильного функционирования российских компаний на территории РФ, как никогда важно поддерживать их устойчивое состояние и за рубежом. Большинство важных международных проектов не могут не пройти без участия Российской Федерации. Как правило, Россия в таких случаях выступает как главный экономический партнёр. По этой причине, стремление западных стран-партнеров создать прецедент для разрыва всех договоренностей, снижается. В частности, когда это касается совместных энергетических проектов. Иными словами, понимание роли Российской Федерации другими странами, появляется возможность проанализировать проблемные сферы сотрудничества и усмотреть перспективы сотрудничества, несмотря на возникающие трудности в санкционный период.

Такое применительно к крупнейшему магистральному газопроводу «Северный поток- 2», который в последнее время является предметом спора между государствами-участниками проектами и странами-противниками. Как известно, проект предполагает развитие торгового сотрудничества в сфере поставки газа. Завершение проекта предусматривает развитие экономического сектора, как для России, так и для стран-участников проекта, позволяет поставлять российский газ вдвое дешевле американского в Европу. Завершив проект, Россия расширит сотрудничество в сфере энергетики и смежных отраслях. На данный момент проект готов на 98\% и, фактически, проект завершается исключительно силами России, поскольку после 
очередного ввода санкций со стороны США многие западные компании прекратили свою деятельность в прокладке трубопровода.

Подобное отношение со стороны США, а именно применение санкций, показывает вмешательство во внутренние дела, нарушая тем самым основополагающие принципы международного сотрудничества. Попытки установить своё мировое лидерство лишь подрывают возможность для взаимного диалога. Однако стоит отметить, что, несмотря на односторонние действия, проект будет завершен и даст стимул для дальнейшего сотрудничества. Такой пример показывает способность России противостоять нависающим угрозам в виде санкций и разрывов соглашений.

С постоянным изменением конъюнктуры международных отношений, эксперты рассуждают о том, какие перспективы есть у России в условиях санкций? Директор департамента общеевропейского сотрудничества МИД России Николай Кобринец дал оценку происходящим внешнеполитическим событиям: «Мы санкции с Евросоюзом не обсуждаем. Не мы их вводили, не нам от них отказываться. Будем жить в тех условиях, в которых мы живём. Они продлеваются регулярно, раз в полгода, ничего нового в этом нет. Перспективы их отмены, скажем так, более чем туманны». По его мнению, с новыми санкциями Россия становится более самодостаточной страной, при этом существует группа стран, считающей санкции преградой для сотрудничества.

Заместитель главы МИД РФ Александр Грушко со своей стороны отметил, что остается возможность для перспективного сотрудничества между Россией и Европейским Союзом в сфере энергетики, машиностроения, обрабатывающей промышленности, а также в сфере информационных технологий. При этом Грушко подчеркнул, что самым главным для развития отношений остается желание западных коллег - дать возможность для развития сотрудничества, а не наоборот.

Россия всегда была и остается приверженцем честных, открытых взаимоотношений, основанных на незыблемых принципах международного сотрудничества. Страны, чьи интересы не соответствуют интересам России, продолжают оказывать давление на Россию, нарушая многие договоренности. Россия со своей стороны продолжает действовать в рамках международного права. Любые односторонние действия, включая санкции, нельзя рассматривать как способ сдерживания России. Такое поведение демонстрирует лишь деструктивный характер во взаимоотношениях между 
Россией и Западными партнерами. На примере санкций, можно отметить, что с одной стороны применение их в сторону России сдерживает мировой экономический обмен, а с другой показывает Россию как страну, способную противостоять международным угрозам и продолжать сотрудничество. Восстановление взаимоотношений, отмена санкций, открытость к совместному диалогу - это все возможно предположить в перспективном будущем между Россией и странами-партнерами, однако данные перспективы не имеют инициативы со стороны Западных стран, поскольку они руководствуются собственными принципами. Поэтому в ближайшем будущем Россия продолжит функционировать самостоятельно, сохранять стойкость и демонстрировать свои возможности в случае, если очередной поток односторонних действий вновь будет представлен извне.

\section{Список литературы}

1. Антироссийские санкции: история и современность: информационноаналитический вестник / под ред. А. П. Кошкина. - Вып. 7. - Москва : ФГБОУ ВО «РЭУ им. Г. В. Плеханова», 2016. - 92 с

2. Кнобель, А. Ю., Багдасарян, К. М., Лощенкова, А. Н., Прока, К. А. Санкции: всерьез и надолго / А. Ю. Кнобель, К. М. Багдасарян, А. Н. Лощенкова, К.А. Прока. - М. : Издательский дом «Дело» РАНХиГС, $80 \mathrm{c.}$

\section{Электронные ресурсы}

1. Газета «Московский Комсомолец» г. URL: https://www.mk.ru/economics/2021/03/13/severnyy-potok2-gotov-na-98-sostavshimisya-dvumya-bolshie-problemy.html [Дата обращения 14.03.2021]

2. Информационное агентство "Интерфакс"- онлайн-сессия "Примаковских чтений" на тему "ЕС нового поколения", стратегическая автономия: мифы или реальность?" URL: https://www.youtube.com/watch?v=4utccFVLI98 [Дата обращения 17.02.2021]

3. Интервью с Заместителем главы МИД РФ Александром Грушко. 04.02.2021 г. ИНТЕРФАКС URL: https://www.interfax.ru/ [Дата обращения 17.02.2021] 